\title{
Serum ferritin levels in inflammation: a retrospective comparative analysis between COVID-19 and emergency surgical non- COVID-19 patients
}

Filippo Banchini ${ }^{*} \mathbb{D}$, Gaetano Maria Cattaneo and Patrizio Capelli

\begin{abstract}
Background: SARS-CoV-2 infection has spread worldwide, and the pathogenic mechanism is still under investigation. The presence of a huge inflammatory response, defined as "cytokine storm," is being studied in order to understand what might be the prognostic factors implicated in the progression of the infection, with ferritin being one of such markers. The role of ferritin as a marker of inflammation is already known, and whether it changes differently between COVID and non-COVID patients still remains unclear. The aim of this retrospective analysis is to understand whether the inflammatory process in these two types is different.

Methods: In this retrospective analysis, we compared 17 patients affected by SARS-CoV-2, who had been admitted between February and April 2020 (group A) along with 30 patients admitted for acute surgical disease with SARSCoV-2 negative swab (group B). A further subgroup of Covid negative patients with leukocytosis was compared to group A.

Results: In group A, the median (interquartile range) serum ferritin was $674(1284) \mathrm{ng} / \mathrm{mL}$, and it was double the cutoff (300 ng/mL) in 9 out of $17(52 \%)$. The median (IQR) value of ferritin level in the total blood samples of group B was 231, and in the subgroup with leucocytosis, 149 (145). Group A showed a significantly higher ferritin median level compared to the entire group $B$ (two-tailed Mann-Whitney test, $p<0.0001$ ) as well as to the subgroup with leucocytosis $(p<0.0014)$.

Conclusions: The role of iron metabolism appears to be directly involved in COVID infection. On the other hand, in the acute inflammation of patients admitted for surgery, and probably in other common phlogistic processes, iron modifications appear to be self-limited. However, our finding suggests the use of ferritin as a marker for COVID infection.
\end{abstract}

Keywords: COVID, SARS-CoV-2, Ferritin, Sepsi, Surgery, Hepcidin, Transferrin, Iron

*Correspondence: filippobanchini@virgilio.it

Department of General Surgery, Guglielmo da Saliceto Hospital, Piacenza,

Italy

(c) The Author(s). 2021 Open Access This article is licensed under a Creative Commons Attribution 4.0 International License, which permits use, sharing, adaptation, distribution and reproduction in any medium or format, as long as you give appropriate credit to the original author(s) and the source, provide a link to the Creative Commons licence, and indicate if changes were made. The images or other third party material in this article are included in the article's Creative Commons licence, unless indicated otherwise in a credit line to the material. If material is not included in the article's Creative Commons licence and your intended use is not permitted by statutory regulation or exceeds the permitted use, you will need to obtain permission directly from the copyright holder. To view a copy of this licence, visit http://creativecommons.org/licenses/by/4.0/. The Creative Commons Public Domain Dedication waiver (http://creativecommons.org/publicdomain/zero/1.0/) applies to the data made available in this article, unless otherwise stated in a credit line to the data. 


\section{Background}

Coronavirus disease 19 (COVID-19) is a complex multisystemic disease whose pathogenesis is still being studied. Going by the clinical evidence, and the data reported in current literature, most COVID-19 patients develop an abnormal inflammatory response to the viral infection, leading to multiorgan failure and death (https://www.who.int/emergencies/diseases/novelcoronavirus-2019/question-and-answers-hub/q-a-detail/ $\mathrm{q}$-a-coronaviruses\#: :text=symptoms). The inflammatory process due to SARS-CoV2 infection may play a main role in the pathogenesis of multiple organ damage and be responsible for the dramatic outcome of COVID-19 patients. The early identification of COVID-19 patients with negative prognostic factors might be quite useful in the management strategy, in order to limit severe complications and eventual death. Inflammatory markers include white blood cell count, lactate dehydrogenase, Creactive protein, fibrinogen, and $\mathrm{D}$-dimer, which are commonly used in clinical practice to monitor the process of sepsis [1, 2]. In literature, it established that iron metabolism is involved in several pathogenetic disease mechanisms, including infections and various hematological and immunological disorders [3].

Recent data as reported in the current literature show that iron metabolism can undergo significant modifications which can be employed in predicting mortality even in patients admitted in intensive care units. Furthermore, serum ferritin has been recently cited as one of the indicators of mortality in COVID-19 patients [4]. Therefore, we decided to investigate serum ferritin as a marker of inflammation, comparing COVID-19 patients admitted into our Emergency Department for acute respiratory syndrome to non-COVID-19 patients which were hospitalized for acute surgical diseases in our Emergency Surgery Department. Our study aims to understand if serum ferritin could be used as an early laboratory marker to identify and classify COVID-19 patients.

\section{Patients and methods}

This is a retrospective observational study involving two cohort groups of patients. Regarding the first cohort, of 101 patients admitted for COVID-19 infection from February 27 to April 28, 2020, at the Emergency Medical Ward of "Guglielmo da Saliceto" Hospital in Piacenza, Emilia-Romagna, Italy, 78 (77.2\%) had been excluded due to the absence of ferritin evaluation, and 6 for negative SARS-CoV-2 swab. The remaining 17 patients diagnosed with COVID-19 pneumonia made up group A (11 males - 64\%; 6 females, mean age 68.8). Regarding the second cohort, 30 patients (17 males $-56 \%$; 13 females, mean age 66.2) with double negative nasopharyngeal swab for SARS-CoV-2 admitted from August 25 to
September 15, 2020, to the Emergency Surgical Ward of "Guglielmo da Saliceto" for acute surgical disease composed group $\mathrm{B}$. There were no comorbidity differences between the two groups $(\mathrm{A}=2 ; \mathrm{B}=2.7)$ in terms of age over 65, diabetes, cardiovascular events, hypertension, obesity, kidney disease, and previous cancer history.

In group A, all patients were positive for $2019-\mathrm{nCoV}$ by real-time polymerase chain reaction from the nasopharyngeal swab [5] and had been investigated upon admission with bedside lung ultrasound and chest CT scan, which demonstrated interstitial pneumonia at different stages. White blood count and serum values of Creactive protein $(\mathrm{CRP})(\mathrm{nv} 0-0.5 \mathrm{ma} / \mathrm{dL})$ and ferritin $(\mathrm{nv}$ $12-300 \mathrm{ng} / \mathrm{mL}$ ) were quantified in all patients enrolled in the study. Data collected were analyzed to check differences in the two groups-COVID-19 versus nonCOVID-19, particularly to understand the relationship between the inflammatory processes and serum ferritin levels in COVID-19 patients.

In our study, we ascertained the hypothesis of serum ferritin as a marker of SARS-CoV2 infection, which could be a simple and useful laboratory test to identify and monitor the inflammatory process in COVID-19 patients.

\section{Results}

In group A, a total of 101 patients were hospitalized in the Emergency Ward. 17 (16,8\%) of them died during hospitalization, $21(20,7 \%)$ were transferred to other hospitals due to either the worsening of the respiratory failure or the lack of beds in our Intensive Care Unit, while $63(62 \%)$ were discharged home. Only $23(22,7 \%)$ of them had their serum ferritin measured during hospitalization, 6 of which were excluded due to the absence of positive SARS-CoV-2 swab.

The median (interquartile range) serum ferritin value was $674(1284) \mathrm{ng} / \mathrm{mL}$, and it was double the cutoff $(300 \mathrm{ng} / \mathrm{mL})$ in 9 of 17 patients $(52 \%)$. Levels in deceased patients were 1981, 1563, 239, 7438, and 344 with a median (IQR) value of 1563 (1637); in patients transferred to continue treatment in other hospitals: 110, 219, 1903, and 3194, with a median value of 355 (1032); and in patients discharged at home: $279,674,790,906,726,462,2181$, and 72 , with a median value of 700 (761).

In group B, a total of 30 patients admitted for an acute surgical problem were examined. Patients characteristics were as follows: six patients had acute appendicitis, one perforated peptic ulcer, three colonic perforations, two neoplastic intestinal obstructions, eight intestinal obstructions that did not require surgery, three acute cholecystitis, three acute diverticulitis Hinchey 1, two obstructed hernia, one perianal abscess, and one traumatic splenectomy. Iron status was evaluated once in 20 
patients, twice in 5 patients, three times in 2 patients, and four times in 3 patients, with a total of 48 blood samples. In this group, ferritin levels were increased in 13 out of 48 blood samples (27\%), with a top value of 804. High white blood cell count and CRP (cutoff $>5$ $\mathrm{mg} / \mathrm{dL}$ ) were present in 20 and 24 samples respectively. Leucocytosis was present in 16 patients and, in this subgroup, simultaneous augmented ferritin was present in 3 out of the 16 cases (18\%), while CRP was over the cutoff in 10 out of $16(62 \%)$. The median (IQR) value of ferritin level in total blood samples of group B was 231 and, in the subgroup with leucocytosis, 149 (145).

Group A showed a significantly higher median level of ferritin in comparison with the entire group B (two-tailed Mann-Whitney test, $p<0.0001$ ), even when also compared to the subgroup with leucocytosis $(p<0.0014)$ (see Figs. 1 and 2). Further analysis of group B was done in patients with leucocytosis, using only the corresponding maximal values of leucocytes registered for each patient compared to group A (see Figs. 3, 4, 5, and 6)

In group $\mathrm{A}$, ferritin levels were over the cutoff value in 12 out of $17(70.5 \%)$, whereas in group B, it occurred only in $27 \%$ of cases and in $18 \%$ of cases when leucocytosis was also present. Moreover, an extreme discrepancy in ferritin values was present between the two groups. In group B, when ferritin was increased, it exceeded two times the cutoff only in 3 out of 48 samples (6\%), compared to 9 out of 17 patients (56\%) in group $\mathrm{A}$.

Finally, incredibly high ferritin levels were present in group A, with up to 24 times (7438) or 7 times (2181) the cutoff.

\section{Discussion}

When an infection occurs, the inflammation process goes through SIRS (systemic inflammatory response syndrome), then SEPSIS, and subsequently SEVERE SEPSIS. The International Sepsis Definitions Conference [1] defined the criteria for SIRS as the presence of two or more of the following parameters: body temperature $>$ $38^{\circ} \mathrm{C}$ or $<36{ }^{\circ} \mathrm{C}$, heart rate $>90$ beats $/ \mathrm{min}$, respiratory rate $>20$ breaths $/ \mathrm{min}$ (or arterial pCO $2<32 \mathrm{mmHg}$, indicating hyperventilation), white blood cell count $>12.0$ $\times 109 / \mathrm{L}$ or $<4.0 \times 109 / \mathrm{L}$ (or $>10 \%$ immature forms), sepsis $=$ infection + SIRS, and severe sepsis $=$ sepsis + evidence of organ dysfunction.

The parameters commonly used to monitor inflammation process and sepsis evolution are lactate, $\mathrm{C}$-reactive protein, procalcitonin, and, more recently, TNF, IL1beta, and IL-6. The mortality rate remains high (30\%), revealing that our knowledge of sepsis is not well understood, and there is no specific treatment yet [6].

Although ferritin is reported as an acute-phase protein, there is literature lacking in reporting the particular modified levels, leading to a misunderstanding regarding its interpretation [7]. Recently, the role of IL-6 has become a key marker in COVID patients, and the classical parameters used for sepsis score do not clarify or answer some of the questions posed by the cytokine storm. The link between IL-6 and iron metabolism is well known [8], but iron parameters are not yet considered a standard biomarker to monitor septic evolution. Even in most recent guidelines for COVID (COVID-19) [2] or in reports about sepsis [9], there is no mention of ferritin, transferrin, or other iron parameters. However, in a recent prospective analysis presented by Brandtner [10],

\section{Ferritin levels}

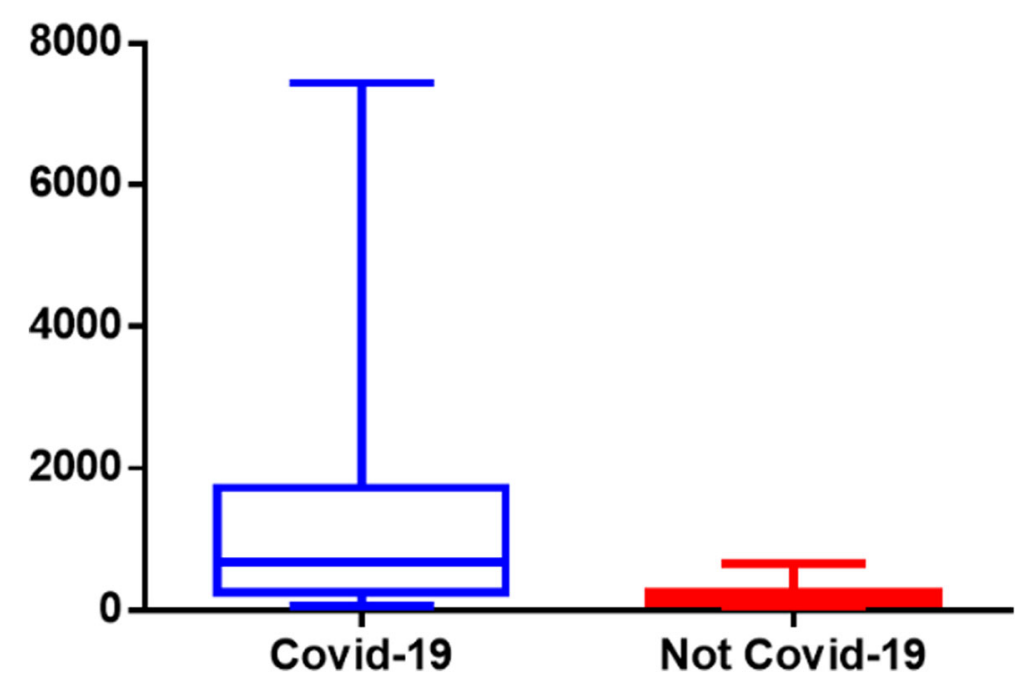

Fig. 1 Median interquartile levels of COVID versus not-COVID patients 


\section{Ferritin levels}

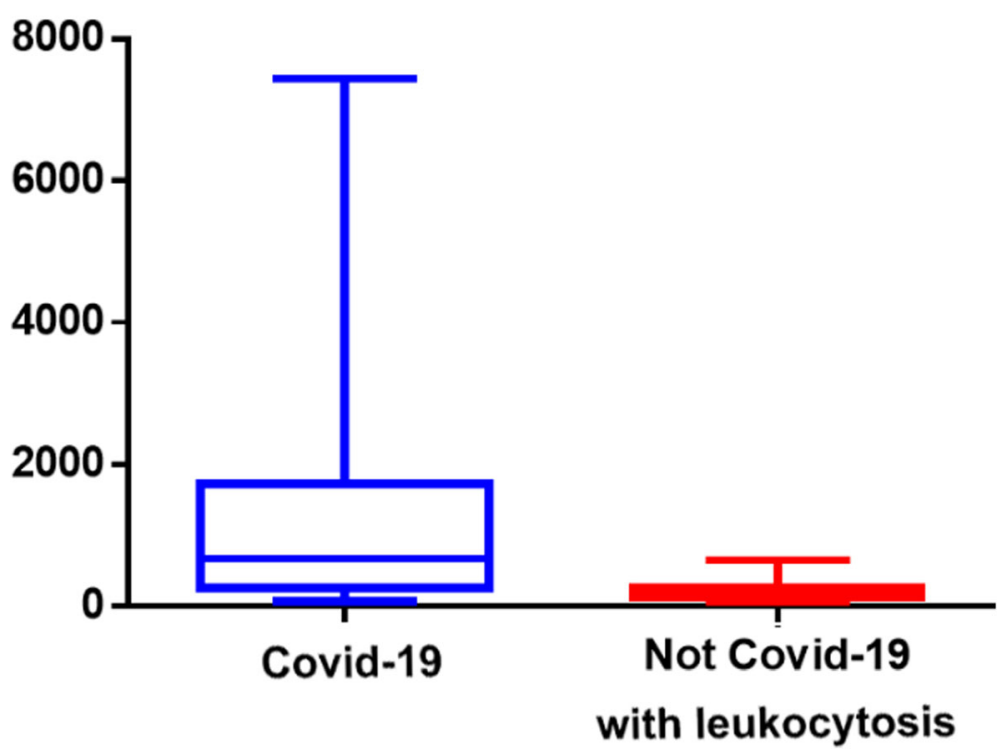

Fig. 2 Median interquartile levels of COVID versus not-COVID with leucocytosis

iron parameters such as ferritin and transferrin saturation levels both correlate with SOFA score (Sequential Organ Failure Assessment) with a significative value: $p=$ 0.043 and $p=0.034$, respectively.

As mentioned in our study, the inflammatory process we are looking for seems different in the usual acute inflammation like emergency surgery than it appears in COVID patients. In patients admitted for acute abdomen or other surgical pathology, the acute inflammatory process correlates with the standard parameters but not with ferritin modification. On the contrary, in COVID patients, iron modification seems to occur immediately. In a recent meta-analysis published by Zeng [11], ferritin had been considered only in 4 of the 16 studies analyzed, but he underlined that ferritin levels could classify COVID patients' severity. This reflects the fact that very few studies at the moment consider iron metabolism in COVID and non-COVID patients. To emphasize the opposite, we cite as an example one of the patients described in our study, who was admitted for acute peritonitis due to rectal perforation, with WBC of 27, 000 , neutrophil count $90 \%$, CRP of 36 , and with a ferritin level of 657 , which was lower than the median value among discharged patient in COVID group.

It is necessary to dig deep into ferritin formation in order to gain more knowledge regarding the processes that are comprised, where IL- 6 and other factors play a significant role. Ferritin production occurs when intracellular iron concentration augments, with iron being stored in the form of ferritin and subsequently expelled from the cell. Intracellular iron accumulation occurs in two main modalities: hyperexpression of Transferrin receptor 1 which internalizes transferrin, and hepcidin

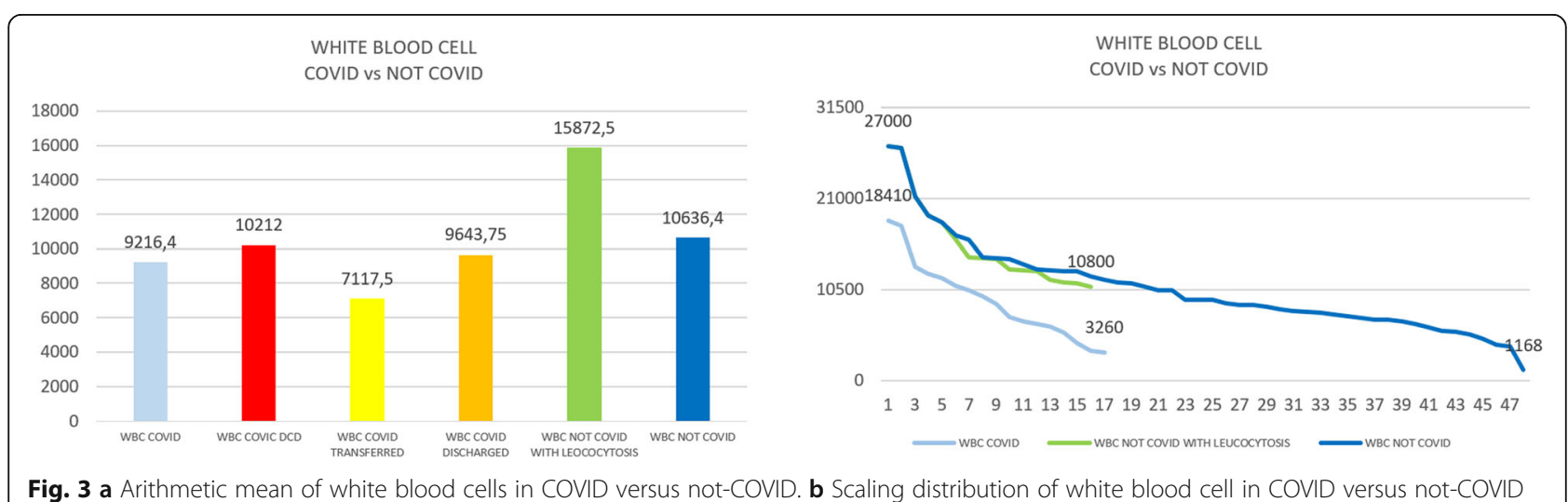

Fig. 3 a Arithmetic mean of white blood cells in COVID versus not-COVID. b Scaling distribution of white blood cell in COVID versus not-COVID 


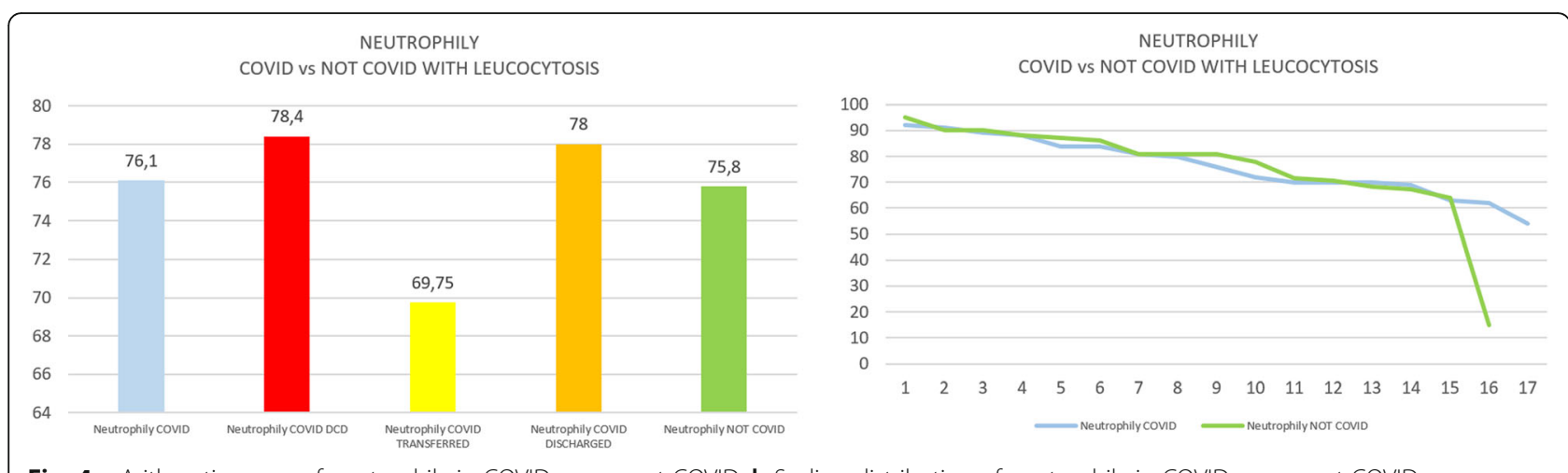

Fig. 4 a Arithmetic mean of neutrophily in COVID versus not-COVID. b Scaling distribution of neutrophily in COVID versus not-COVID

expression. Hepcidin inhibits iron ions expulsion blocking ferroportin, which is the only siderophore of the cells.

Interestingly, in a recent publication of Jiang [12] about patients admitted in ICU, high hepcidin levels were directly related to mortality with a superior predictive value as well as a high specificity compared to other inflammatory parameters. Furthermore, as Kell explained in 2014, ferritin is not only related to the inflammation process but could be a direct indicator of cellular damage, especially when its value is over $600 \mathrm{ng} / \mathrm{mL}$ [13], implying a direct relationship between organ damage and ferritin formation.

The hyperactivation of this process causes cell death by so-called ferroptosis. This latter becomes one of the mechanisms described in acute respiratory distress syndrome (ARDS), quite similar to COVID pneumonia.

Following these observations, we might suggest that the usual inflammatory process starts with the classical SIRS-SEPSIS and subsequently affects iron metabolism. In contrast, in COVID patients, iron modifications occur as a first step, followed by SIRS, and likely resulting in a sort of severe sepsis. Furthermore, ferritin could be evaluated in surgical patients with negative SARS-CoV-2 swab as an indirect marker, in order to verify if they have been affected by COVID disease during their hospitalization, and as an indicator of severe sepsis at the same time.

Considering the lack of data presented in our study in the Group of COVID patients, we cannot confirm with statistical significance a direct correlation between COVID severity and ferritin levels, even though we could suggest it as supported by most recent literature data. On the contrary, we may confirm the absence of hyperferritinemic syndrome at the beginning of the usual inflammatory process and assess which values could be related to this phlogistic reaction phase.

Recent literature advocates hyperferritinemic syndrome as one of the main modifications in COVID infection [14-19], suggesting evaluation of ferritin levels as a parameter of infection. Presently, excluding reviews and metanalysis, only ten papers have been published with the contemporary topic of "ferritin" and "COVID" [20-29]. Moreover, we have suggested the evaluation of ferritin in COVID infection in our previous reports [30, 31]. This lack of literature reflects the low usage of iron parameters in common practice as revealed from our analysis in group A, which occurred at the beginning of the pandemic spread in Italy. Also, as Bataille [24] presented on 22 patients, this parameter can become useful in asymptomatic patients, and be used as a possible
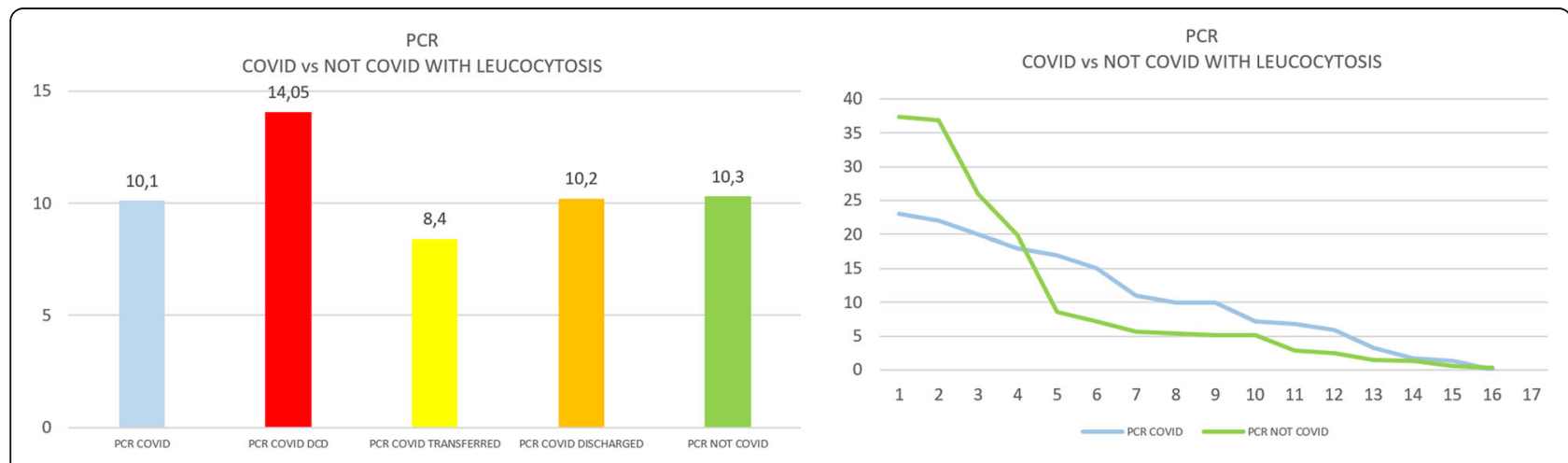

Fig. 5 a Arithmetic mean of C-reactive protein in COVID versus not-COVID. b Scaling distribution of C-reactive protein in COVID versus not-COVID 


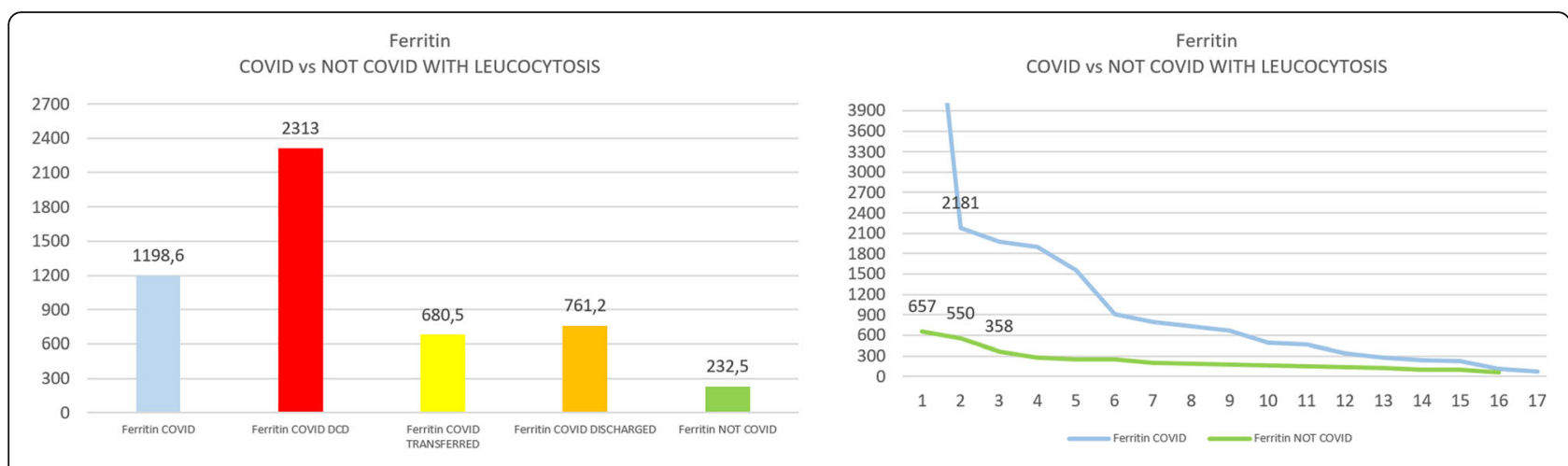

Fig. 6 a Arithmetic mean of Ferritin in COVID versus not-COVID with leucocytosis. b Scaling distribution of Ferritin in COVID versus not-COVID with leucocytosis

discriminant between COVID and non-COVID pneumonia, as posted by Garanti [29].

This study has several limitations, in particular, the narrow number of patients enrolled mainly due to an unusual serum ferritin testing in the initial period as well as its retrospective nature. Therefore, a wider analysis would be necessary in order to prove our outcomes.

\section{Conclusions}

Even if ferritin is considered an acute-phase protein, its role in monitoring inflammation is still not very clear and, for this reason, it is not used routinely. The role of iron metabolism in COVID infection is increasing even without an accurate interpretation, and our study seems to confirm this observation. In the acute inflammation of surgical patients admitted for a procedure, and probably in other classical inflammation processes, iron modifications appear to be self-limited. However, our finding suggests the use of ferritin values as a marker for COVID infection.

\section{Abbreviations}

CRP: C-reactive protein; nv: Normal value; IQR: Interquartile range; SIRS: Systemic inflammatory response syndrome; SOFA: Sequential Organ Failure Assessment; ICU: Intensive care unit; WBC: White blood cell; ARDS: Acute respiratory distress syndrome

\section{Acknowledgements}

Collaboration: Agrusti Sonia; Arzu Gian Domenico; Baldini Edoardo; Caizzone Antonio; Cambrini Paolo; Conti Luigi; Delfanti Rocco; Ferri Eugenio; Filosa Mauro; Giannone Giancarlo; Girardi Andrea; Girardi Rodolfo; Grassi Carmine; Isolani Simone Mario; Luzietti Enrico; Mazzilli Massimiliano; Mosso Federico; Negri Carlo; Percalli Luigi; Piccioni Pierfausto; Piccolo Davide; Regina Gabriele; Ribolla Marta; Santi Andrea; Scabini Matteo; Tagliaferri Daniele. Special thanks to Dr. Ekpo Ekerette Francis (Medical Officer, General Hospital, Pankshin, Plateau state, Nigeria) for language revision.

\section{Authors' contributions}

Banchini Filippo is the promoter. He conceived the study, collected data, interpreted data, and wrote the manuscript. Gaetano Maria Cattaneo approved the manuscript. Patrizio Capelli approved the manuscript. Coauthors in acknowledgments supported the data collection, and they all assisted the COVID patients during the first wave of the pandemic.

\section{Authors' information}

The study analysis derives from a previous report published in Acta Biomedica Parmensis about iron metabolism in COVID patients with the title: "Iron overload and Hepcidin overexpression could play a key role in COVID infection, and may explain vulnerability in elderly, diabetics, and obese patients. Acta Biomed. 2020 Sep 7;91(3):e2020013. doi: 10.23750/ abm.v91i3.9826. PMID: 32921750."

\section{Funding}

No funding is present for any of the authors.

\section{Availability of data and materials}

Separate files with anonymous content data are uploaded with the manuscript submission.

\section{Declarations}

\section{Ethics approval and consent to participate}

This is a retrospective analysis of a small group of patients, and the ethics committee approval was not asked, as indicated by Article 9 EU GDPR "Processing of special categories of personal data" Paragraph 1 (j), and Article 89 EU GDPR "Safeguards and derogations relating to processing for archiving purposes in the public interest, scientific or historical research purposes or statistical purposes."

\section{Consent for publication}

Individual personal data are not directly published in the manuscript and, in order to guarantee and respect individual privacy, data do not suggest any recognition of patients.

\section{Competing interests}

The authors declare that they have no competing interests.

Received: 5 December 2020 Accepted: 23 February 2021

Published online: 08 March 2021

\section{References}

1. Levy MM, Fink MP, Marshall JC, Abraham E, Angus D, Cook D, Cohen J, Opal SM, Vincent UL, Ramsay G. SCCM/ESICM/ACCP/ATS/SIS. 2001 SCCM/ESICM/ ACCP/ATS/SIS International Sepsis Definitions Conference. Crit Care Med. 2003;31(4):1250-6. https://doi.org/10.1097/01.CCM.0000050454.01978.3B.

2. Alhazzani W, Møller MH, Arabi YM, Loeb M, Gong MN, Fan E, Oczkowski S, Levy MM, Derde L, Dzierba A, Du B, Aboodi M, Wunsch H, Cecconi M, Koh Y, Chertow DS, Maitland K, Alshamsi F, Belley-Cote E, Greco M, Laundy M, Morgan JS, Kesecioglu J, McGeer A, Mermel L, Mammen MJ, Alexander PE, Arrington A, Centofanti JE, Citerio G, Baw B, Memish ZA, Hammond N, Hayden FG, Evans L, Rhodes A. Surviving sepsis campaign: guidelines on the management of critically ill adults with Coronavirus Disease 2019 (COVID-19). Intensive Care Med. 2020:46(5):854-87. https://doi.org/10.1007/ s00134-020-06022-5. 


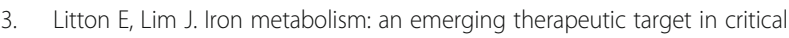
illness. Crit Care. 2019;23:81. https://doi.org/10.1186/s13054-019-2373-1.

4. Vargas-Vargas M, Cortés-Rojo C. Ferritin levels and COVID-19. Rev Panam Salud Publica. 2020;44:e72. https://doi.org/10.26633/RPSP.2020.72.

5. World Health Organization. Novel coronavirus (2019-nCoV) technical guidance: laboratory testing for 2019-nCoV in humans 2020. https://www. who.int/emergencies/diseases/novel-coronavirus-2019/technical-guidance/la boratory-guidance. Accessed May 2020

6. Faix JD. Biomarkers of sepsis. Crit Rev Clin Lab Sci. 2013;50(1):23-36. https:// doi.org/10.3109/10408363.2013.764490.

7. Rosário C, Zandman-Goddard G, Meyron-Holtz EG, D'Cruz DP, Shoenfeld Y. The hyperferritinemic syndrome: macrophage activation syndrome, still's disease, septic shock, and catastrophic antiphospholipid syndrome. BMC Med. 2013;11:185. https://doi.org/10.1186/1741-7015-11-185.

8. Narazaki M, Kishimoto T. The two-faced cytokine IL-6 in host defense and diseases. Int J Mol Sci. 2018;19(11):3528. https://doi.org/10.3390/ ijms19113528.

9. Bateman RM, Sharpe MD, Jagger JE, Ellis CG, Solé-Violán J, López-Rodríguez $M$, et al. 36th International Symposium on Intensive Care and Emergency Medicine: Brussels, Belgium. 15-18 March 2016. Crit Care. 2016;20(Suppl 2): 94. https://doi.org/10.1186/s13054-016-1208-6 Erratum in: Crit Care. 2016 Oct $24 ; 20: 347$

10. Brandtner A, Tymoszuk P, Nairz M, Lehner GF, Fritsche G, Vales A, Falkner A, Schennach H, Theurl I, Joannidis M, Weiss G, Pfeifhofer-Obermair C. Linkage of alterations in systemic iron homeostasis to patients' outcome in sepsis: a prospective study. J Intensive Care. 2020;8:76. https://doi.org/10.1186/s4 0560-020-00495-8.

11. Zeng F, Huang Y, Guo Y, Yin M, Chen X, Xiao L, Deng G. Association of inflammatory markers with the severity of COVID-19: a meta-analysis. Int J Infect Dis. 2020;96:467-74. https://doi.org/10.1016/j.jid.2020.05.055.

12. Jiang $Y$, Jiang $F Q$, Kong F, An MM, Jin BB, Cao D, Gong P. Inflammatory anemia-associated parameters are related to 28-day mortality in patients with sepsis admitted to the ICU: a preliminary observational study. Ann Intensive Care. 2019:9(1):67. https://doi.org/10.1186/s13613-019-0542-7.

13. Kell DB, Pretorius E. Serum ferritin is an important inflammatory disease marker, as it is mainly a leakage product from damaged cells. Metallomics. 2014;6(4):748-73. https://doi.org/10.1039/c3mt00347g.

14. Colafrancesco S, Alessandri C, Conti F, Priori R. COVID-19 gone bad: a new character in the spectrum of the hyperferritinemic syndrome? Autoimmun Rev. 2020;19(7):102573. https://doi.org/10.1016/j.autrev.2020.102573.

15. Ruscitti $P$, Berardicurti $O$, Di Benedetto $P$, Cipriani $P$, lagnocco $A$, Shoenfeld Y, Giacomelli R. Severe COVID-19, another piece in the puzzle of the hyperferritinemic syndrome. An immunomodulatory perspective to alleviate the storm. Front Immunol. 2020;11:1130. https:// doi.org/10.3389/fimmu.2020.01130.

16. Perricone C, Bartoloni E, Bursi R, Cafaro G, Guidelli GM, Shoenfeld Y, Gerli R. COVID-19 as part of the hyperferritinemic syndromes: the role of iron depletion therapy. Immunol Res. 2020;68(4):213-24. https://doi.org/10.1007/ s12026-020-09145-5.

17. Alunno A, Carubbi F, Rodríguez-Carrio J. Storm, typhoon, cyclone or hurricane in patients with COVID-19? Beware of the same storm that has a different origin. RMD Open. 2020;6(1):e001295. https://doi.org/10.1136/ rmdopen-2020-001295.

18. Ruscitti P, Giacomelli R. Ferritin and severe COVID-19, from clinical observations to pathogenic implications and therapeutic perspectives. Isr Med Assoc J. 2020;8(22):450-2.

19. Fisler G, Haimed A, Levy CF, Stiles J, Capone CA, Fish JD, Brochstein JA, Taylor MD. Severe coronavirus disease 2019 infection in an adolescent patient after hematopoietic stem cell transplantation. Chest. 2020;158(4): e139-42. https://doi.org/10.1016/j.chest.2020.05.579.

20. Zhou C, Chen Y, Ji Y, He X, Xue D. Increased serum levels of hepcidin and ferritin are associated with severity of COVID-19. Med Sci Monit. 2020;26: e926178. https://doi.org/10.12659/MSM.926178.

21. Feld J, Tremblay D, Thibaud S, Kessler A, Naymagon L. Ferritin levels in patients with COVID-19: a poor predictor of mortality and hemophagocytic lymphohistiocytosis. Int J Lab Hematol. 2020. https:// doi.org/10.1111/ijlh.13309.

22. Tural Onur S, Altın S, Sokucu SN, Fikri Bi, Barça T, Bolat E, Toptas M. Could ferritin level be an indicator of COVID-19 disease mortality? J Med Virol. 2020. https://doi.org/10.1002/jmv.26543.
23. Dahan S, Segal G, Katz I, Hellou T, Tietel M, Bryk G, Amital H, Shoenfeld Y, Dagan A. Ferritin as a marker of severity in COVID-19 patients: a fatal correlation. Isr Med Assoc J. 2020;8(22):429-34.

24. Bataille $\mathrm{S}$, Pedinielli N, Bergounioux JP. Could ferritin help the screening for COVID-19 in hemodialysis patients? Kidney Int. 2020;98(1):235-6. https://doi. org/10.1016/j.kint.2020.04.017.

25. Lin Z, Long F, Yang $Y$, Chen $X, X u L$, Yang M. Serum ferritin as an independent risk factor for severity in COVID-19 patients. J Infect. 2020;81(4): 647-79. https://doi.org/10.1016/j.jinf.2020.06.053.

26. Gharamti AA, Mei F, Jankousky KC, Huang J, Hyson P, Chastain DB, Fan J, Osae S, Zhang WW, Montoya JG, Erlandson KM, Scherger SJ, Franco-Paredes C, Henao-Martínez AF, Shapiro L. Diagnostic utility of a ferritin-toprocalcitonin ratio to differentiate patients with COVID-19 from those with bacterial pneumonia: a multicenter study. medRxiv. 2020;22:2020.10.20. 20216309. https://doi.org/10.1101/2020.10.20.20216309.

27. Fauter M, Viel S, Zaepfel S, Pradat P, Fiscus J, Villard M, Garnier L, Walzer T, Sève $P$, Henry $T$, Jamilloux $Y$. Low glycosylated ferritin is a sensitive biomarker of severe COVID-19. Cell Mol Immunol. 2020;17(11):1183-5. https://doi.org/10.1038/s41423-020-00544-0.

28. Venter C, Bezuidenhout JA, Laubscher GJ, Lourens PJ, Steenkamp J, Kell DB, Pretorius E. Erythrocyte, platelet, serum ferritin, and p-selectin pathophysiology implicated in severe hypercoagulation and vascular complications in COVID-19. Int J Mol Sci. 2020;21(21):E8234. https://doi.org/1 0.3390/ijms21218234.

29. Gandini O, Criniti A, Ballesio L, Giglio S, Galardo G, Gianni W, Santoro L, Angeloni A, Lubrano C. Serum ferritin is an independent risk factor for acute respiratory distress syndrome in COVID-19. J Infect. 2020;15:S01634453(20)30617-4. https://doi.org/10.1016/j.jinf.2020.09.006.

30. Banchini F, Vallisa D, Maniscalco P, Capelli P. Iron overload and Hepcidin overexpression could play a key role in COVID infection, and may explain vulnerability in elderly, diabetics, and obese patients. Acta Biomed. 2020; 91(3):e2020013. https://doi.org/10.23750/abm.v91i3.9826.

31. Banchini F. COVID-19 and NF-kB: the Hepcidin paradox and the iron storm reply. Acta Biomed. 2020;91(4):e2020137. https://doi.org/10.23750/abm.v91 i4.10904.

\section{Publisher's Note}

Springer Nature remains neutral with regard to jurisdictional claims in published maps and institutional affiliations.

Ready to submit your research? Choose BMC and benefit from

- fast, convenient online submission

- thorough peer review by experienced researchers in your field

- rapid publication on acceptance

- support for research data, including large and complex data types

- gold Open Access which fosters wider collaboration and increased citations

- maximum visibility for your research: over $100 \mathrm{M}$ website views per year

At $\mathrm{BMC}$, research is always in progress.

Learn more biomedcentral.com/submissions 